\title{
Job Switching Of Garment Workers Decreasing Productivity: An Analytical Research

\author{
${ }^{1}$ Najmul Kadir Kaikobad, ${ }^{2}$ Md Zafar Alam Bhuiyan, \\ ${ }^{I}$ Assistant Dean \& Center Head, Shanto-Mariam University of Creative Technology, City campus, Lalmatia, \\ Dhaka,Bangladesh \\ ${ }^{2}$ Assistant Proctor \& Lecturer of Fashion Design, Shanto-Mariam University of Creative Technology, City \\ campus, Lalmatia, Dhaka, Bangladesh
}

\begin{abstract}
Frequent job changing or migration creates huge problems in production and management in the readymade garments sector of Bangladesh. Job changing or migration is very common character for professions but frequently change make the system interrupted. Garments workers change their jobs for higher salary, bad environment, transportation, housing and related others problems related with their working stations. From the research it was revealed that lots of job opportunities for the garments workers makes them easy to find out the better option, though their working environment almost same in everywhere excepting some special cases. Mainly the workers change their jobs for higher salaries, increasing house rent where the female for good environment, good communication and harassment free working condition. Three areas of Dhaka district have been selected for this study where two areas from Dhaka city and another one is outer side of Dhaka city. The comparative study has come here regarding their job change from city to outer city area. Workers job changing for higher salary and good environment is almost common to everywhere but for increasing house rent and communication, the workers of city area change their jobs normally.
\end{abstract}

Key Words:

BGMEA-Bangladesh Garments manufacturers and Exporters Association

BKMEA-Bangladesh Knitwear manufacturers and Exporters Association

Eid day-The holy day for Muslim People

MFA -Multi-Fiber Arrangement of RMG

NGO-Non Government Organization

PENSION BIMA-Insurance for the retired people in future.

POHELA BAISHAKH -First day of Bangla year

PROSHIKA- an NGO works in Bangladesh

SSC-Secondary School Certificate

Taka (TK)-Money of Bangladesh .80 Taka=1 US\$

\section{Introduction:}

Job switching of garment workers from one factory to others is a big concern today. Bangladesh is the hub of garment factories for different causes. Cheap labor cost is the main cause of mushrooming garment factory in Bangladesh. Availability of the human resources is the main cause of low cost of labor. Agriculture was the main profession of the country which is decreasing day by day for the shortage of agricultural land enough. On the other hand, most of the marginal farmers are shifting themselves from agriculture to others professions claiming they are least benefitted there. On the contrary, our agriculture is suffering from lack of workers because, the workers have shifted them in other professions like garment sector. But, paradoxically still garments sector is suffering from the shortage of workers. Labor migration is the common phenomenon is this sector. For which lots of problems arise causing low production and failure to shipment in scheduled time. Recently, a research team of Shanto-Mariam University of Creative Technology, Dhaka, Bangladesh, has made a research on garment workers' job switching at Rampura , Badda and Savar areas of Dhaka district. For this study 20 workers were selected male and female randomly from each area. Here an analytical research was done regarding the low productivity of garments where many components were discussed relating job switching of the garments workers.

\section{Review of Literature:}

\subsection{Bangladesh is the country of Garments Industries/Back Ground:}

Bangladesh is a developing country. Most of the people are still occupied in agriculture sector. But per capita land is very scant. The majority of our farmers are the marginal farmers. Others rural workforce is involved with day labors, however some people are engaged in others small scale industries like handicrafts which are yet to be boomed to earn huge currency to involve the enormous unemployed manpower. The 
Successful export oriented readymade garments industry (RMG)which is now earning more than $78 \%$ of our foreign export of Bangladesh (BGMEA,2012), has observed remarkable growth since its beginning late 1970s.Paradoxically, this flagship industry of Bangladeshi private entrepreneurial talent took roots through the first export shipment of shirts from Bangladesh made by state trading agency, the Trading Corporation of Bangladesh (TCB) in the mid -1970s (Rashid, 2006), under the country trade administration \& the destination was some East European Countries. Consequently, however, private entrepreneurs entered the industry and phenomenal growth took place in RMG exports from Bangladesh. Export of RMG increased from US \$40 thousand in 1978-79 to US $\$ 6.4$ billion in 2004-05.The industry has also provided employment to nearly 3.2 million workers (BGMEA, 2012) most of them women drawn from the rural areas.

Unstable growth of RMG exports is not inimitable to Bangladesh. The annual compound growth rate of RMG export industries in Indonesia (31.2\%), Mauritius (23.8\%) \& Dominican Republic (21.1\%) compares favorably with that of Bangladesh (81.3\%) over the 1980-87 periods (Rashid,2006). Though, while the early situation was favorable for export growth in the countries noted above, this was far from the reality in case of Bangladesh. This makes research into the factors responsible for the observed outstanding growth of RMG exports from Bangladesh-a persuasive case study in economic development.

This is true that the remarkable development of RMG export from Bangladesh to favorable external conditions, notably the Multi-Fiber Arrangement (MFA) bilateral quota system imposed by developed apparel countries, and low wages in Bangladesh. The role played by helpful government policy has also been noted in these studies. This obvious incredulity in the dynamics and creativity of Bangladeshi RMG entrepreneurs seems to have sprung from the more general conception, widely held by many scholars during the 1970s and 1980s, that Bangladesh lacks entrepreneurial possessions.

Rising of RMG industry in Bangladesh happen during a time when the economy's health was poor shape and it was overwhelmed by various problems both structural and policy-induced in nature, which inhibited, among other things, growth of manufacturing industries in the country, the work forces related to this, including govt. had to fight a lots to peruse these from the each corner, while unsuitable government policy can hex digester for an industry, by the same logic, sound economic policy of the government can stimulate industrial growth. There is unanimity of opinion among scholars that the changing structure of the global apparel industry has been uniquely fashioned by the MFA Quota system used by the developed importing countries which restricted export supplies of garments to these markets from the established supplying countries and thereby paved the way for the emergence of new garments exporting countries. This migration of the export oriented garments industry from the established suppliers to the new suppliers was, as one would expect, directed by the existence of the wages in the new exporting countries.

Prior to the innovation of Garments industry of late 1970s the unemployed were the burden to the Agro based economy of Bangladesh. Then the following social problems were found in the rural areas of Bangladesh which used lead the country as a country of poor, poorly developed infra structures, lack of education, Social unrest, Malnutrition, Marriage in underage, Polygamy, Dirty village politics, etc.

\subsection{Others' Study:}

Labor switching is a big concern in Readymade garments sector of the country. It creates huge problem in the production planning and finally in the output. From the intensive literature review from internet, newspapers and interviews of the production personnel's and factory owners it was revealed that it is creating huge troubles in the whole readymade garment sector of the country. According to a research conducted by Nazneen and Mahfuz (2010), female workers do not change frequently their jobs. About 41\%Male and skilled workers change their jobs within 1-3yrs of their job experiences. On the other hand, $49.67 \%$ female workers do not change their job in the same time. Male workers (58.12\%) shift their jobs basically for higher wages whereas the female workers $(44.35 \%)$ for the good environment (for free from abuse, good transportation, compliance, etc. Job environment is the very important factor for the female workers. But in their field survey, job environment was quite good while only $14 \%$ of female workers were dissatisfied with the factory environment. In the same research it was found that female workers harassment was common. More than 50\% of female workers were harassed by physically, mentally, sexually in their job stations. On the other hand, 49.7\% female workers said that there was no harassment in their works.

Bangladesh has strong labour law of The Bangladesh Labour Act, 2006; Factories Act 1965 and factories rule 1979 for the protection of labours from harassment and to establish their rights, but most of the garments workers are not conscious about the law and Acts (Mahmud, 2009).There is a strong clause in the Factory rule1979 that labourers can make trade unions to establish their rights and regulating the good relation between workers and the employers, but most of the factory owners are seriously against the trade unions. On the other side Garments owners and managements are fearful about the impaction of innovation of trade unions as this have somewhat paralysed Banking and transport sectors of Bangladesh (Khan, 2009).Mr Julius (43), factory manager of a garment factory from Savar, claimed that labourers were threatening him by the trade union involving with local political leaders for higher salary, better facilities, etc. while the union leaders' output 
is very poor. Nowadays, labour unrest is the big problem of the readymade garments industry of the country. Increasing rate of education, awareness have created the consciousness of the labourers about their rights. According to BGMEA it is the result of national and international conspiracy against the garments industry of the country whereas the political leaders claimed that this is the result of voracious and stubborn nature of the factory owners (Mahmud, 2009)

\section{Need/Importance Of The Study:}

Bangladesh earns $78 \%$ of her foreign earning by exporting readymade garments a (BGMEA, 2012).about 3.2 millions workers are working there when more than 150 millions of people are dependent to this sector (Mahmud, 2009). This is the main foreign business of the country. On the other hand, this is the largest knit garments manufacturer of the world. Nowadays, China, India, Cambodia and Sri Lanka are the main competitors of Bangladesh for garments sector. Labour migration and Labour unrest are making the country threatened to lose the sector to the competitors though the rate of investment is still increasing as the cheapest production cost in the world. Skilled workforce is the main asset of the country for the sustainable development of this sector. Research on this sector can find out the problems and solutions for maximise the development and sustainability in the long run.

\section{Statement Of The Problem:}

Skilled labours are still scarce in the garments industry of Bangladesh. Though the involvement and investment in this sector are increasing day by day, average production is not increasing instead of innovation and using of modern equipments and machineries. Migration or switching of the workers creates low production, failure the production planning, failure to meet the demand of the buyers and low income successively. More than 500 garment factories have closed their operation since last 5 years incurring their loss due to low production resulting from labour switching, migration, labour unrest, etc. (BGMEA,2012).

\section{Objective:}

To find out the problems along with the solutions of labour switching or migration so that further development can be done in this sector. Though the age of the of the garment industry is about 40 years, still production, skills of the work force are not in increasing rate( Khan, 2009), which is alarming for all.

\section{Hypotheses:}

1. Labour switching or migration from one factory to another has a serious impact on production in garment sector of Bangladesh.

2. Wages, increasing rate of house rent, transportation, factory environment, festival events, are the main causes of labour switching.

\section{Research Methodology:}

Research team has selected two areas of Dhaka city Rampura and Badda and another area Savar, an outer area of Dhaka district. All the areas basically famous for garment factories of the country. From each area, 20 garments workers(from different factories) were selected as random basis from both male and female for this study who have switched their jobs from one factory to another at least 2 to 5 times. They were interviewed with a standard questionnaire to find out the related information from them from which the actual causes of their factory switching has been revealed. Factory owners and managements were kept behind so that they can feel free to express themselves and for their job security as the authority sometimes does not appreciate them to talk with media, or research team being fearful mind secret of the management would be opened . After the field survey of the garments workers, the research team also talked with 9 garments owners ( 3 from the each areas) with another questionnaire to find out the management related causes of labour switching and the related loss incurring for the same. After that, the result of the both field surveys have been analysed by line diagram to show the result visually and easy to understand by all.

\section{Results \& Discussion:}

For the result analysis and discussion very simple statistical presentation has been selected for the easy understating of all considering the level of standard of the research materials and method. There may be a lot of causes for the migration of labours from one factory to another but the major causes have analysed in the following. The result in the following may differ from the other side or in the other district, like Chittagong, Gazipur, Nrayangonj, etc. Data analysis in the following is the basis of random sampling method of the particular areas. 
8.1. Good Salary and Benefits: It is very easy to get a job as a helper in any garment of the city as there is shortage for that. Without any prior experience, even an illiterate can get a job over night. The starting salary is Tk.2000 to TK.2500 per month. An unskilled worker works there 6 to 8 months and has a common tendency to shift from the same factory to others as an operator with a higher salary. Sometimes, they make group and leave the factory in a body for other factory. Result of the field data is given below:

\begin{tabular}{|c|c|c|c|c|c|c|c|c|}
\hline Area & $\begin{array}{c}\text { Total } \\
\text { Migrating } \\
\text { workers }\end{array}$ & $\begin{array}{c}\text { Migrating } \\
\text { workers } \\
\text { for good } \\
\text { salary }\end{array}$ & Percentage & Male & Percentage & Female & Percentage & $\begin{array}{c}\text { Average } \\
\text { Job } \\
\text { duration }\end{array}$ \\
\hline Badda & 20 & 4 & 20 & 3 & 75 & 1 & 25 & 11 months \\
\hline Rampura & 20 & 7 & 35 & 5 & 71 & 2 & 29 & 14 months \\
\hline Savar & 20 & 7 & 35 & 6 & 85.7 & 1 & 14.3 & 9 months \\
\hline
\end{tabular}

8.2. Transportation: For garment workers transportation is a huge problem. Most of the time they have to leave their works after evening when there is a huge rush in the road which is somewhat impossible for them to hire a rickshaw or others transportation to reach their home. Finding no alternative, they have to walk a long distance. In the monsoon they suffer much as they have to reach their works on time, sometime they are with wet dressing and all the daylong the wet cloths get dry in wearing their body.

\begin{tabular}{|c|c|c|c|c|c|c|c|c|}
\hline Area & $\begin{array}{c}\text { Total } \\
\text { Migrating } \\
\text { workers }\end{array}$ & $\begin{array}{c}\text { Migrating } \\
\text { workers for } \\
\text { Transportation }\end{array}$ & Percentage & Male & Percentage & Female & Percentage & $\begin{array}{c}\text { Average } \\
\text { Job } \\
\text { duration }\end{array}$ \\
\hline Badda & 20 & 3 & 15 & 0 & 0 & 3 & 100 & $\begin{array}{c}9 \\
\text { months }\end{array}$ \\
\hline Rampura & 20 & 4 & 20 & 1 & 25 & 3 & 75 & $\begin{array}{c}12 \\
\text { months }\end{array}$ \\
\hline Savar & 20 & 3 & 15 & 1 & 33.33 & 2 & 66.67 & $\begin{array}{c}7 \\
\text { months }\end{array}$ \\
\hline
\end{tabular}

8.3.Effect of festival events: In every year, there are two Eids (Muslim people have two Eids one is after Ramadan which is called Eidul Fitre and another is around 75 days after Eidul Fitre called Eidul Azha) garments workers get leave for around 7 to 10 days with their advance salary, bonus and others benefits. Sometimes this is more than double of their regular monthly income. In the Eid vacation they themselves or their guardians arrange their marriage. Their life profiles get change and sometimes they get delay to join their previous work. Their spouses every so often force them to quite their job (especially in case of women) .In some cases, a woman gets marry with other factory worker, finds comfort to work in the same factory. Which ultimately result is migration from one factory to another.

\begin{tabular}{|c|c|c|c|c|c|c|c|c|}
\hline Area & $\begin{array}{c}\text { Total } \\
\text { Migrating } \\
\text { workers }\end{array}$ & $\begin{array}{c}\text { Migrating } \\
\text { workers for } \\
\text { Festival } \\
\text { events }\end{array}$ & Percentage & Male & Percentage & Female & Percentage & $\begin{array}{c}\text { Average } \\
\text { Job } \\
\text { duration }\end{array}$ \\
\hline Badda & 20 & 4 & 20 & 2 & 50 & 2 & 50 & $\begin{array}{c}12 \\
\text { months }\end{array}$ \\
\hline Rampura & 20 & 1 & 5 & 0 & 0 & 1 & 100 & $\begin{array}{c}12 \\
\text { months }\end{array}$ \\
\hline Savar & 20 & 5 & 25 & 1 & 20 & 4 & 80 & $\begin{array}{c}11 \\
\text { months }\end{array}$ \\
\hline
\end{tabular}

8.4. Sexual Harassment \& Awful behavior: Still it is very common problem in the readymade garment sector that, women workers are being harassed by their co-workers, supervisors, and production people or by the more powerful person of the factory. Though the owners association (BGMEA and BKMEA) have strong position against this with govern of Bangladesh, sometimes the victims are helpless for the situations.

\begin{tabular}{|c|c|c|c|c|c|c|c|c|}
\hline Area & $\begin{array}{c}\text { Total } \\
\text { Migrating } \\
\text { workers }\end{array}$ & $\begin{array}{c}\text { Migrating } \\
\text { workers for } \\
\text { sexual } \\
\text { harassment \& } \\
\text { awful } \\
\text { behaviour }\end{array}$ & Percentage & Male & Percentage & Female & Percentage & $\begin{array}{c}\text { Average } \\
\text { Job } \\
\text { duration }\end{array}$ \\
\hline
\end{tabular}


Job Switching Of Garment Workers Decreasing Productivity: An Analytical Research

\begin{tabular}{|c|c|c|c|c|c|c|c|c|}
\hline \hline Badda & 20 & 5 & 25 & 1 & 20 & 4 & 80 & 6 months \\
\hline Rampura & 20 & 3 & 15 & 1 & 33 & 2 & 67 & 8 months \\
\hline Savar & 20 & 2 & 25 & 0 & 0 & 2 & 100 & 3 months \\
\hline
\end{tabular}

On the other hand, it's a great regret that still garments workers are orally abused seriously by their supervisors, peers and by other people involved in the management. Sometimes, they become physically assaulted for their minor faults. Roni (34 years old), an operator of Line Fashion Limited claimed that he was physically assaulted by his supervisor for using toilet only for two minutes. Basher, another sample man of 41 years old was threaten for using mobile phone even in his leisure time in the dining space.

Figure 01: Migration of Garments Workforce in three areas of Dhaka

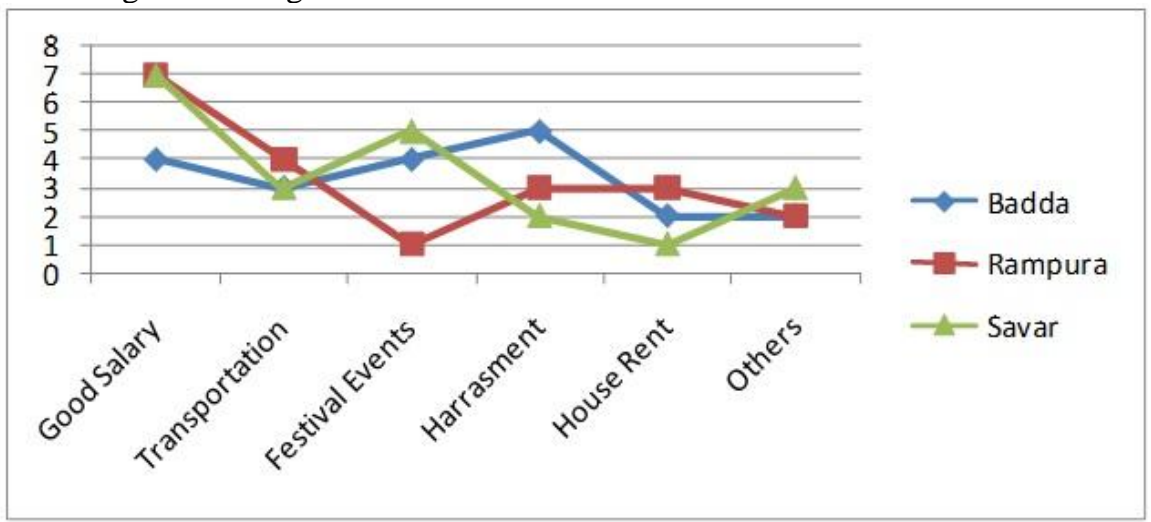

8.5. House Rent: it's a great issue for the garments workers who are working Rampura and Badda areas. 'Uncontrolled increasing rate of house rent has driven away many good workers from the city to Savar or Narayangonj'-this is a direct quotation of Abdul Baset, Owner of Knit Fashion Factory in Rampura. In the survey it was revealed that house rent in some specific areas where the garments workers live has increased 30$47 \%$ by 1 year, which is somewhat impossible to meet by the little earning garments workers. In Savar, comparatively its effect is lesser as it is really an area for garment industries.

\begin{tabular}{|c|c|c|c|c|c|c|c|c|}
\hline Area & $\begin{array}{c}\text { Total } \\
\text { Migrating } \\
\text { workers }\end{array}$ & $\begin{array}{c}\text { Migrating } \\
\text { workers } \\
\text { for } \\
\text { increasing } \\
\text { rate of } \\
\text { house } \\
\text { rent }\end{array}$ & Percentage & Male & Percentage & Female & Percentage & $\begin{array}{c}\text { Average } \\
\text { Job } \\
\text { duration }\end{array}$ \\
\hline Badda & 20 & 2 & 10 & 1 & 50 & 1 & 50 & 10 months \\
\hline Rampura & 20 & 3 & 10 & 1 & 33 & 2 & 67 & $\begin{array}{c}14 \\
\text { months }\end{array}$ \\
\hline Savar & 20 & 1 & 5 & 1 & 100 & 0 & 0 & 7 months \\
\hline
\end{tabular}

8.6. Others: A good number of garment factory environments are not up to the mark for work there in a long time. Research team has found most of the factories located in Badda and Rampura in Dhaka city is congested with much people in small space. Sewing or even finishing space is small, inadequate facility for workers, shortages of refreshing room including toilet, etc. A worker of Tuba fashion limited from Badda said that she left her previous work station only for inadequate facility for toilet there in. There were common toilets for male and female which were unhygienic. It was found in some cases that workers leave without any cause but the termination or simply for the shifting of their co-workers. Shilpy (22 years old), a helper said that she left her previous work place as her husband was terminated by the authority.

\begin{tabular}{|c|c|c|c|c|c|c|c|c|}
\hline Area & $\begin{array}{c}\text { Total } \\
\text { Migrating } \\
\text { workers }\end{array}$ & $\begin{array}{c}\text { Migrating } \\
\text { workers } \\
\text { for other } \\
\text { causes }\end{array}$ & Percentage & Male & Percentage & Female & Percentage & $\begin{array}{c}\text { Average } \\
\text { Job } \\
\text { duration }\end{array}$ \\
\hline Badda & 20 & 2 & 10 & 1 & 50 & 1 & 50 & 11 months \\
\hline Rampura & 20 & 2 & 10 & 1 & 50 & 1 & 50 & $\begin{array}{c}13 \\
\text { months }\end{array}$ \\
\hline Savar & 20 & 3 & 15 & 1 & 33 & 2 & 67 & 11 months \\
\hline
\end{tabular}




\section{Findings:}

From the analysis it is found that, most of the male workers are changing their jobs for good salary. In Badda, from total 20 migrated workers, 4 have changed their jobs only for good salary, where 3 are male workers and 1 is female. This is the common scenario also for the other two areas (Rampura and Savar) that for good salary mainly male workers are shifting their jobs. On the other hand, majority of the female workers change their jobs for transportation, good environments, harassments, etc. After the festival events, both male and female change their jobs which higher rate at Savar for female workers and at Badda for the same for male workers. For house rent, mainly male workers are changing their jobs inside the areas of Dhaka city, which tendency is lesser in the outer area of Dhaka (Savar).In the whole study, it is found that, highest rate of job changing for good salary by the male workers both inside and outer side of Dhaka city while highest rate for female workers job changing for good environment and to be free from harassments. Moreover, garments workers are prone to change their jobs within 15 months of their service life.

\section{Recommendations/Suggestions:}

1. Garments workers salary should be as per the rules of the Bangladesh government and Bangladesh Labor law. Workers should be duly paid to uplift the environment of the working condition of garments factories.

2. According to Buyers Code of Conduct, garments should be fully compliance, for instance, many of the factories still maternity leave is not approved for the pregnant workers though it is compulsory for every owner of garments industry of Bangladesh.

3. Good transportation should be ensured for both the male and female workers so that they easily can transport from their residences to works and vice versa.

4. Garment owners should arrange residential places for the workers to be ensured their commitments of the workers so that they don't need to think for their job change for the increasing rate of house rent. For this, garments owner can seek housing space for the govt. from the Khas or vested land of the country. Though Govt has taken initiative for the same (BGMEA, 2011) but work for the same is still in snail pace.

\section{Conclusions:}

Garments are the main work place of the nation for the foreign earnings. They earn the breads of the country people; though the total environment of the country is not favorable to them. For the production, changing jobs frequently by the garments workers is very much hampering to meet the buyers' demand on time. Government of the country as well as the garments owners associations (BGMEA and BKMEA) should be more conscious about their insufficient earnings, their little demand such as optimum salary as they deserve, good working condition, educational facilities of the kids and others for the development of this sector.

\section{Scope For Further Research:}

There are a lot of scopes for further research about garments sector of the country. A comparable study can be done male and female workers of the garments workers relating their changing jobs, though a little analysis has been shown in this research paper. Further research also can be done about the consciousness of the garments owners for the compliance issues enacting by the govt. and buyers readymade garments industries

\section{Acknowledgments:}

The paper here attempts to highlights the total picture queue of the garments factories for the workers for the causes of their job switching. One of the research team has served as a merchandising manager in a garment factory before joining Shanto-Mariam University of creative Technology. Several times he felt in trouble for labour switching as labour is the heart of production. On time salary, optimum salary, good transportation, good environment are the rights of the workers for good production and sustainability for the same. Regarding our this research one thing was in our mind that we would find out the actual causes for the labour switching in the garments factory whatever it might be. We (Najmul and Zafar), and a group of our students leading by Md.Najmul Islam Polash \& Md.Atikur Rahman, students of $5^{\text {th }}$ Semester, BA (Hons) in Fashion Design helped us in the data collection from the field. Factory owners, Management, specially Mr. Julius, Factory Manager; Merchandising Mnager Mr.Hannan ,Oekotex helped us a lots. We are grateful to them. We hope this research will help to guide future researchers, factory owners and management in the long run.

\section{References:}

[1] Abdel-Latif, Abla M. (1993). "The non price determinants of export success or failure: the Egyptian ready-made garments industry, 1975-1989" World Development, Vol. 21, No.10, pp.1677-1684

[2] Ahmed, Razib (2009). Impact of Global Economic Recession on Nepalese Economy,http://search.msn.com/results.aspx?srch=106 \& Form=Effect of economic recession of RMG sector of Bangladesh.

[3] Asiatic Society of Bangladesh (2006) "Garment Industry" in Banglapedia, Asiatic society of Bangladesh, Retrieved August 7, 2006 fromhttp://banglapedia.org/HT/G_0041.HTM 
[4] Bangladesh Garments Manufacturers And Exporters Association (BGMEA)-Government recognized trade body of the garments factories of Bangladesh, <www. bangladesh garments. Info>accessed during the period 2003-2007

[5] Bhuiyan, Z.A. (2008). Marketing Prospect of Product Design and Development of Bangladesh, Seminar Paper with Net herein University, Germany.

[6] Bhuiyan, Z.A. (2012). "Present Status of Garment workers in Bangladesh: An analysis", International journal of Business and Management, Vol: X, Issue: X

[7] BBS (1989) "Report on Labor Force Survey 1989", Bangladesh Bureau of Statistics, Government of Bangladesh, Dhaka

[8] BBS (1991) "Report on Labor Force Survey 1991", Bangladesh Bureau of Statistics, Government of Bangladesh, Dhaka

[9] Bangladesh Institute of Management (1999) "Impact study on Enforcement of Labor Laws Relating to Women Workers in the Garments Industry", BIM, Dhaka

[10] BGMEA (2007) Directory of the Bangladesh Garments Manufacturers Association 2006-07

[11] Bhatty, Z.(1980) "Economic Roles and status of Women: A case study of Women in the Bead industry in Allahabad", Working Paper, ILO, Geneva.

[12] Bhattacharya, Debapriya (2007).Bangladesh's apparel Sector in Post -MFA period: A benchmarking study ongoing Restructuring Process, A publication by Center for Policy Dialogue (CPD)

[13] Export promotion Bureau, Bangladesh (EPB)www.epbd.com/,accessed during 200-2007.

[14] Haider, Mohammed Z.(2006) "Export performance of Bangladesh textile and garments industry in major international market"

[15] Hamid,S.(1989) “women's Non-market works and GDP Accounting:The case of Bangladesh"Research Report No.116,Bangladesh Institute of development Sudies,Dhaka

[16] Haque, Ahasanul (2002).Global Marketing of Readymade Garments Products from Bangldesh: Market Prospect and Challenges., Pakistan journal of Applied Science 2(10): 975-979

[17] Latif, M.A.(1994) "The Program Impact on Current Contraception in Bangladesh" The Bangladesh Development Studies,Vol.XXII,NO.1.

[18] Mainuddin, Khandaker(2000). Case of Garments industry of Dhaka, Bangladesh, Urban and Local Government background series, No.6 (Washinton, D.C., World Bank)

[19] Mukta,Z.H.(2001) The rights of Female Workers (in Bengali),Karmajibi Nari,Dhaka

[20] Morshed, M.Monjur (2007). A study on labor rights implementation in readymade garments (RMG) industry in Bangladesh: Bridging the gap between theory and practice, 2007, University of Wollongong, University theses collection.

[21] Shikder,N.B.(2002) "Women Garment Workers In Bangladesh "doctoral Thesis in the Department of Sociology, University of Manchester, UK

[22] Shimu,S.D.(1999) Garments Workers: Movement and Struggle(in Bengali),Nari Grantha Probontona, Dhaka

[23] Zohir, S.C.(2001) "Social Impact of Growth of Garments Industry in Bangladesh "The Bangladesh Development Studies, Vol.XXVII,No.4,pp 41-80 